\title{
Nye litteraturer: Litterære tekstpraksiser hos voksne innvandrere i norsk grunnskoleopplæring
}

\author{
Lene Anundsen \\ Universitetet i Agder
}

\begin{abstract}
Sammendrag
Voksne innvandrere som tar norsk grunnskoleeksamen har teksterfaringer fra litterære tradisjoner som kan være ukjente $\mathrm{i}$ vår sammenheng. Basert på nærmere tyve enkeltintervjuer undersøker denne studien både tidligere og nåværende litterære tekstpraksiser hos informanter fra Syria, Eritrea og Somalia. Ett av studiens funn er at enkelte informanter med svært lite skolegang likevel har aktive litterære tekstpraksiser. Imidlertid vil de fleste litterære tekstpraksisene sannsynligvis ikke bli gjenkjent i skolesammenheng, ettersom de opptrer utenfor skolens domene og bare unntaksvis er knyttet til trykte, papirbaserte tekster, som bøker. I stedet er youtube det mest brukte mediet. Studien argumenterer for å utvide og nyfortolke fagfeltet «litteratur» gjennom å inndra litterære tradisjoner fra andre deler av verden i større grad, samt ved å interessere seg for litteratur som praksis, inspirert av den etnografiske tradisjonen fra «New Literacy Studies».
\end{abstract}

Nøkkelord: Litteraturdidaktikk; migrasjon; skjult literacy; littercert repertoar; littercere tekstpraksisers funksjoner; overgang mellom praksiser

\begin{abstract}
New Worlds of Literature: The Literary Practices of Adult Immigrants in Norwegian Lower Secondary School

This study investigates the literary practices of learners attending lower secondary school as part of adult education in Norway. Based on almost twenty research interviews with learners from Syria, Eritrea and Somalia, the study indicates that though several learners have received little formal education, they nevertheless have active literary practices. In Norwegian schools, however, these practices are likely not to be acknowledged, as they mostly occur outside of the school domain, and only rarely center on printed texts or books. Instead, youtube is the main resource. The study argues that the field and teaching of "literature» will benefit on a broader, more global view, and also from approaching literature as a social practice, influenced from ethnographic traditons from "New Literacy Studies".
\end{abstract}

Keywords: Literature didactics; migration; invisible literacy; literary repertoire; functions of literary practices; practices in transition

Redaktør: Atle Skaftun

Mottatt: August, 2019; Godkjent: December, 2019; Publisert: February, 2020

^Korrespondanse: Lene Anundsen, Universitetet i Agder, epost: lene.anundsen@uia.no

(C) 2020 Lene Anundsen. This is an Open Access article distributed under the terms of the Creative Commons Attribution 4.0 International License (https://creativecommons.org/licenses/by-nc/4.0/), allowing third parties to copy and redistribute the material in any medium or format and to remix, transform, and build upon the material for any purpose, even commercially, provided the original work is properly cited and states its license.

Citation: Lene Anundsen. "Nye litteraturer: Littercere tekstpraksiser hos voksne innvandrere i norsk grunnskoleopplaring" Nordic Fournal of Literacy Research, Vol. 6, 2020, pp. 49-66. http://dx. doi.org/10.23865/njlr.v6.1855 


\section{Anundsen}

\section{Innledning}

Jeg liker - hva er «shaear» på norsk? Dikt? Jeg liker dikt ... Nizar Qabbani? Hver dag jeg hører på han, på youtube ... Også, har mange dikt, arabic. (Sami, 31, Syria)

I vignetten ovenfor beskriver Sami det jeg i denne artikkelen kaller en litterær tekst-praksis; gjentatte hendelser (praksis) der en litterær tekst inngår som en sentral del. Når Sami forteller at han liker dikt og daglig hører på den syriske poeten Nizar Qabbani, dreier det seg om hans individuelle litterære erfaring; et estetisk møte med en litterær tekst (Rosenblatt, 1938/1995), dessuten om en praksis som er sosialt og kulturelt situert (Barton, Hamilton \& Ivanič, 2000). Sami har bodd i Syria inntil relativt nylig, men er nå elev i et norsk grunnskoletilbud organisert gjennom kommunal voksenopplæring. Som del av en kvalitativ studie i litteraturdidaktikk har jeg intervjuet elever fra tre grunnskoleklasser for voksne innvandrere, og denne artikkelen presenterer funn fra studien. Materialet består hovedsakelig av verbaldata fra 18 enkeltintervjuer med informanter ${ }^{1}$ fra Eritrea, Syria og Somalia, der flertallet har migrert til Norge relativt nylig. Artikkelen har to overordnede forskningsspørsmål:

Hvilke litterære tekstpraksiser har informantene med seg fra sitt førsteland?

Hvilken funksjon eller betydning har de litterære tekstpraksisene for informantene her og nå?

Disse spørsmålene vil bli besvart i resultatdelen, der jeg presenterer analysen av det empiriske materialet. Også forholdet mellom tidligere og nåværende tekstpraksiser hos informantene berøres, artikulert gjennom et tredje spørsmål: Hvordan kan informantenes tekstpraksiser forstås som overgangspraksiser, altså som tekstpraksiser i overgang fra én kontekst til en annen? Dette vil jeg kommentere underveis i analysen og oppsummeringsdelen.

\section{Teoretisk rammeverk og sentrale begreper}

Det teoretiske rammeverket for studien er først og fremst hentet fra den etnografiske forskningstradisjonen «New Literacy Studies» (Barton \& Hamilton, 1998; Heath, 1983; Martin-Jones \& Jones, 2000; Street, 1984), men også fra litteraturteori, særlig Kathleen McCormicks sosiokulturelle lesemodell (McCormick, 1994). McCormick beskriver møtet mellom tekst og leser som et møte mellom ulike repertoarer: både tekst og leser er historisk og kulturelt situert, og deres allmenne og litterære repertoarer har betydning for tekstmøtet. Leserens litterære repertoar utgjøres både av

\footnotetext{
${ }^{1}$ Det samlede materialet er fra 22 informanter, men intervjuene med informantene fra Sudan (1), Palestina (1), Afghanistan (1), Laos (1) og Myanmar (1) inngår ikke som materiale for denne delstudien. Jeg bruker nasjonale/etniske betegnelser på informantene (somalier, eritreer osv.) ut fra hvordan informantene selv omtaler sin etniske og språklige tilhørighet, også i de (få) tilfellene der de har vokst opp i eller har statsborgerskap fra et annet land. Plan for datahåndtering er godkjent av NSD. Alle personnavn er fiktive.
} 
leserens kunnskap om, erfaringer med og forventninger til hva litteratur er eller kan være, mens tekstens litterære repertoar særlig dreier seg om sjangertrekk som plot eller metrikk. Det allmenne repertoaret betegner verdier, holdninger og normer; ofte uartikulert eller implisitt til stede både hos leser og tekst. I resultatdelen bruker jeg «litterært repertoar» som analytisk verktøy for å identifisere mønstre i de tre informantgruppenes erfaringer med (litterære) tekster.

Tekstpraksis er et sentralt begrep i artikkelen. I tråd med tradisjonen fra «New Literacy Studies» (NLS) ser jeg på litteratur og litteraturbruk også som en type sosial praksis. Praksisbegrepet åpner for en bred tilnærming: litteratur og litterær tekstpraksis avgrenses ikke til «lesing», og litteratur er heller ikke avgrenset til skriftlige tekster, men inkluderer muntlige litterære tradisjoner og intermediale tekster. Alle tekster som inviterer til eller brukes fortolkende, estetisk eller performativt, blir i denne studien regnet som litterære tekster. Som konsekvens av praksisperspektivet vil analysen sentreres rundt spørsmål om hva, hvordan og hvorfor den enkelte «gjør» (med) litteratur - altså hvilken funksjon de litterære tekstpraksisene har for informantene. Innenfor NLS har flere forskere pekt på hvordan hegemoniske tekstkulturer (skolens tekstkultur brukes ofte som eksempel) bidrar til at «mainstream» literacy fortrenger andre typer literacypraksiser, som dermed risikerer å bli oversett og ikke anerkjent (Gee, 2015; Gregory \&Williams, 2000; Heath, 1983). I norsk sammenheng har Mette E. Nergård og Tove Nicolaysen (Nergård \& Nicolaisen, 2016) introdusert begrepet «skjult literacy» for å beskrive teksterfaringer som i liten grad blir sett, aktivert og tilkjent status i skolens undervisning. Både norsk og internasjonal forskning har vist hvordan «annen» erfaring risikerer å bli oppfattet som «mangel» fordi den avviker fra skolens likhetsdiskurs (Lidén, 2001) eller tatt-for-gitte praksiser (Blackledge, 2000; Gee, 2015). Den kanadiske utdanningsforskeren Diana Masny (Masny, 2010; Masny \& Cole, 2009) bruker Gilles Deleuzes begrep «territory» for å beskrive hvordan literacy-feltet «eies» gjennom rådende definisjoner:

Once a concept is created it is a territory. Take the example of literacy, the ability to read, write and process information (UNESCO, 2008.) Literacy is a concept, a bounded stable territory. Deterritorialization undoes a territory, only to configure a different territory (reterritorialization). (Masny, 2013, s. 340)

Et hegemonisk felt «avterritorialiseres» gjennom «brudd» (disruptions), hevder Masny (Masny, 2013). Bruddene får feltet til å krakelere, noe som muliggiør en redefinisjon eller «reterritorialisering». Et brudd kan for eksempel være når rådende praksisers dominans blir utfordret gjennom at andre, alternative praksiser beskrives, gis verdi og derigjennom også definisjonsmakt. I artikkelen fungerer territorie-begrepet som en overgripende metafor for å formidle studiens ambisjon: å utvide og justere det feltet ("territoriet») som definerer hvordan vi forstår og snakker om litteratur. Anvendt på litteratur- og norskfaget betyr det at når hittil skjulte eller ukjente litterære tekstpraksiser utforskes og beskrives, bringes de inn på feltet, territoriet. Dermed skjer et «brudd»; en oppfordring til å definere feltet på nytt gjennom et utvidet kunnskapsgrunnlag. 


\section{Anundsen}

\section{Aktuell forskning}

Grunnskoleløp for voksne er et nesten ubeskrevet forskningsfelt (Dæhlen, Danielsen, Strandbu \& Seippel, 2013). Selv om det i Skandinavia har blitt publisert en rekke empiriske doktoravhandlinger om litteraturdidaktikk de siste tiårene (Kjelen, 2013; Molloy, 2002; Penne, 2006; Rødnes, 2011; Skarstein, 2013; Tengberg, 2011), hentes empirien i all hovedsak fra det ordinære morsmålsfaget. Litteraturdidaktiske studier om andrespråks-undervisning er sjeldne. Unntak i skandinavisk sammenheng er avhandlingene til Rita Hvistendahl (Hvistendahl, 2000), Elisabeth Ellingsen (Ellingsen, 2013) og Catharina Economou (Economou, 2016). Deres empiri er fra norsk og svensk videregående skole (Hvistendahl og Economou), samt norskkurs for internasjonale studenter (Ellingsen), og belyser blant annet elevenes/studentenes resepsjon av litterære tekster brukt i undervisningen. I denne studien rettes oppmerksomheten mot informantenes egne tekstpraksiser og tekstbakgrunn fra ulike geokulturelle områder, framfor å fokusere på skolens tekster og undervisning. Studien bidrar dermed med et globalt perspektiv på literacy og litteratur. De litterære tekstpraksisene kan forstås som en form for overgangspraksiser, eller det Anne Pitkänen-Huhta og Lars Holm kaller «literacy practices in transition» (Pitkänen-Huhta \& Holm, 2012). Pitkänen-Huhta og Holm sier om egne studier at selv om disse er hentet fra Norden, skal de ikke dermed forstås som geografisk avgrensede, men som «.... a space which is connected to other spaces in multiple ways» (Pitkänen-Huhta \& Holm, 2012, s. 12). I Joke Dewildes studier av unge enkeltmigranters transspråklige og transkulturelle skrivepraksiser (J. Dewilde, 2017; J. Dewilde \& Skrefsrud, 2016; J. Dewilde, 2018) utmerker spesielt Facebook seg som en type "space» der ungdommers samlede språklige og kulturelle ressurser tas i bruk og transformeres. Også denne studien viser at migrasjonen ikke nødvendigvis innebærer full atskillelse, men at informantene kan være "connected» blant annet gjennom sine litterære tekstpraksiser.

\section{Metode, datamateriale og analyse}

Studien er etnografisk inspirert. Datamaterialet som analyseres er verbaldata fra semistrukturerte enkeltintervjuer med informanter fra tre ulike grunnskoleklasser og med bakgrunn fra Eritrea, Syria og Somalia. De fleste intervjuene ble gjennomført på norsk, ${ }^{2}$ til tross for at mange informanter hadde begrensede norskspråklige ferdigheter. Min bakgrunn som norsklærer innenfor voksenopplæring var antakelig en fordel i intervjusituasjonen. Intervjuene foregikk i skoletida og varte mellom 30-90 minutter. Intervjuguide ${ }^{3}$ ble brukt, men jeg la også vekt på å følge opp

\footnotetext{
${ }^{2}$ Tre av intervjuene i datamaterialet ble gjennomført med tolk, enten telefontolk eller med tospråklig lærer ansatt på opplæringssenteret.

${ }^{3}$ Tema $\mathrm{i}$ intervjuguiden var bl.a. tidligere skolegang, teksterfaringer og praksis fra ulike domener $\mathrm{i}$ hjemlandet, tilgang til bøker, medieformer, tekstpraksis i Norge, lesing på eget språk og norsk i og utenfor skolen.
} 
det informantene selv brakte inn i samtalen. I ettertid ble intervjuene transkribert av meg.

Prosessen med å analysere dataene har foregått i en spiralbevegelse, fra teori til empiri og tilbake igjen, altså en abduktiv tilnærming (Alvesson \& Sköldberg, 2008). Jeg har hatt en eksplorerende tilnærming med en overordnet intensjon om å undersøke informantenes erfaringer og praksis med tekst, primært litterær tekst. Til grunn for analyseresultatene ligger to overordnede valg. For det første valgte jeg tidlig i analyseprosessen å ikke fokusere på tekstpraksiser hvor språklæring er den mest framtredende funksjonen, men heller å undersøke det jeg oppfatter som litterære tekstpraksiser og funksjonene disse kan ha. Funksjonene blir primært (men ikke bare) identifisert på individnivå, og utforskes underveis i resultatdelen.

For det andre har jeg reflektert over hvordan intervjupersonenes tekstpraksiser kan framstilles med ulike fortegn ut fra valg av perspektiv. Datamaterialet har en rekke eksempler som kan fortolkes som at informantene uttrykker lite eller ingen interesse for eller erfaring med litteratur og tekst. Å framheve dette som det vesentligste funnet ville framstilt informantene $i$ et mangelperspektiv, noe som etter min oppfatning bryter det forskningsetiske prinsippet om velgjørenhet (Kvale \& Brinkmann, 2015, s. 107). Jeg har valgt å sette andre funn i forgrunnen, nemlig de litterære tekstpraksisene jeg har funnet hos noen av informantene, også når de representerer et mindretall i det samlede datamaterialet.

Hensikten med sitatene i resultatdelen er dels å la informantene framstå som individer, dels å dokumentere den empirinære og eksplorative analyseprosessen. Utvalget av sitater representerer selvsagt en fortolkning fra min side. Der sitatene etter min oppfatning illustrerer tendenser i materialet, altså at flere informanter uttaler seg nokså likt, markeres dette med alle informantnavnene i parentes. En mulig kritikk mot mine sitatvalg kan være at de ikke speiler det samlede materialet tilstrekkelig. Til det er å si at valgene av hvilke sitater og funn som presenteres og løftes fram, begrunnes gjennom det overordnede prinsippet om synliggiøring og avterritorialisering: Funnene viser et utvalg og en fortolkning av voksne innvandrerelevers teksterfaringer og litterære praksiser som hittil har vært lite beskrevet og derfor ukjent og skjult (Nergård \& Nicolaisen, 2016). Studiens bidrag er ikke å vise de ulike praksisenes representativitet, men relevansen av at de fins. Gjennom dette skjer «bruddet» (Masny, 2013) som slår en sprekk i den hegemoniske forståelsen av faget.

\section{Resultater}

Nedenfor presenterer jeg min analyse av litterære tekstpraksiser og deres funksjoner hos informanter fra henholdsvis Somalia, Syria og Eritrea. Perspektivet veksler mellom individuelt nivå og gruppenivå. Funnene presenteres gruppevis, ettersom informantene deler migrasjon fra spesifikke områder som en avgiørende erfaring. McCormicks begrep «litterært repertoar» (McCormick, 1994) brukes for å undersøke mulige disposisjoner på bakgrunn av teksterfaringene som kommer fram i de 


\section{Anundsen}

ulike gruppene. Å beskrive litterære repertoarer innebærer stilisering og forenkling, og dermed en risiko for at individuelle variasjoner nedtones. Individperspektivet vektlegges imidlertid i det andre analytiske grepet, der oppmerksomheten rettes mot de individuelle tekstpraksisenes ulike funksjoner. Gjennom å veksle mellom individog gruppenivå ivaretas forhåpentlig noe av materialets kompleksitet og variasjon.

\section{Litterære tekstpraksiser hos de somaliske informantene}

Den somaliske informantgruppa består av tre kvinner: Najma (30), Fawzia (36) og Noor (19). De har mellom null (Najma) og ett års (Noor, Fawzia) skolegang fra tidligere. Både informantene og forskningslitteratur om somalisk litterær tradisjon omtaler dikt, gabay, som det mest sentrale litterære uttrykket for somaliere. Ordet gabay brukes ofte om dikt generelt, men betegner egentlig en egen diktsjanger, den mest klassiske og prestisjefylte innenfor somalisk litterær tradisjon. Tradisjonelt har gabay blitt formidlet giennom muntlig framføring og memorering (Andrzejewski, 2011b; Samatar, 2010). En gabay har visse formelle regler som må overholdes, forklarer Najma:

For eksempel, du begynner a, du slutter a. Et system. Ikke opp og ned, ikke opp og ned. Alltid én bokstav, og hva betyr en bokstav - ja. (Najma, 30, Somalia)

Sammen med rytme og skandering er alliterasjon (bokstavrim) det fremste kjennetegnet på en klassisk gabay: at én bokstav gjentas som forlyd i minimum to ord i samtlige linjer av diktet (enkelte gabay er på opptil hundre verselinjer) er altså et litterært-formelt krav for sjangeren (Andrzejewski, 2011a). I somalisk kultur har poesi tradisjonelt vært både utbredt og høyt verdsatt (Samatar, 1982). Muntlig veltalenhet betyr gjennomslagskraft: Said Samatar forklarer poesiens status i Somalia delvis med at «poetry is the medium whereby an individual or a group can present a case most persuasively» (Samatar, 1982, s. 3). Gabay-sjangren rommer alle slags motiv eller tema, den kan handle «om alt», forklarer Fawzia. Enkelte poetiske sjangre er forbeholdt visse domener; buraambur brukes for eksempel først og fremst av kvinner, særlig $\mathrm{i}$ forbindelse med feiringer av forlovelse eller bryllup. Tidligere var gabay som sjanger forbeholdt menn, men skillet er i ferd med å viskes ut (Hoehne \& Luling, 2010). Fawzia forteller at hennes egen mor har laget gabay som har blitt framført på somalisk tv. Najma beskriver sin mormor som spesielt dyktig - hun kunne lage og framføre lange dikt helt spontant:

Ikke tenke! En gang hun, to sider, ${ }^{4}$ hun snakke. Og hun ikke skrive. Bare muntlig! .... Ja, hun er flink. (Najma, 30, Somalia)

Najma er ifølge seg selv «ikke så flink med skriftlig», men likte å lese i oppveksten, både fortellinger, sheeko, og dikt, gabay. Etter at hun kom til Norge leser hun aldri noe på sitt eget språk, forklarer hun, derimot hører hun ofte gabay på youtube. Særlig når

\footnotetext{
${ }^{4}$ Når Najma sier "to sider», oppfatter jeg at hun mener diktet tilsvarer en tekst på to sider, altså et langt dikt.
} 
hun føler seg ensom eller nedfor: i stedet for å ringe venninner for å prate, finner hun en gabay på youtube, gjerne et "dikt til oppmuntring» (gabay dhiirin galin ah). Etterpå føler hun seg sterkere, forklarer hun, og mimer hvordan hun «bretter opp ermene»: «Jeg hørte! Og - jeg litt sterk! ... Etterpå jeg går ut!». For Najma fungerer dikt som en ressurs der hun kan hente emosjonell støtte eller «påfyll»: Hun leter aktivt opp tekster som kan møte hennes behov, og bruker den medieringen som er tilgjengelig $i$ hennes nåværende kontekst - amatørvideoer på youtube.

Noor (19) skiller seg ut gjennom å være den eneste av informantene som også lager egne gabay. Hun tok selv initiativ til å lære seg sjangerkravene da hun gikk på somalisk skole i en flyktningleir. Læreren forklarte henne det viktigste, men i tillegg, understreker Noor, må du også være litt kunstner ("artist») for å lage dikt. Det er ikke så ofte hun dikter, forklarer hun, men hvis hun er veldig engasjert eller frustrert over noe, så «kommer det - som regn!» For et par år siden hadde en kvinnelig slektning av henne problemer på grunn av et dårlig ekteskap. Denne situasjonen opptok Noor så sterkt at hun laget en gabay:

Og en dag, jeg - når du møter en problem, kanskje noen ganger du, sang, eller du skriver noe. Og jeg skriver en gabay. Ja. Så laang! ... Og en gang - jeg forteller min mor, og en dag vi møter henne [slektningen, min anm.], og min mor sier: Noor har laget noe, kan du høre? Og hun hører, og hun gråter, og - alt er for henne, hun føler. Mye. Ja. Da hun sier - jeg må gjøre noe! (Noor, 19, Somalia)

Noors gabay ytrer seg om en konkret situasjon og er preget av en tydelig adressivitet (Bakhtin, 1998). Dette er i tråd med klassisk somalisk poetisk tradisjon, og bekrefter Samatars beskrivelse av poesien som det mediet som "can present a case most persuasively» (Samatar, 1982, s. 3). I Noors litterære tekstpraksis videreføres denne litterære arven. Lite skolegang og ustabile boforhold i oppveksten har gitt Noor varierende tilgang til både skriftlige og muntlige (litterære) tekster. Likevel har hun et aktivt forhold til de poetiske sjangrene gabay og buraaambur og muntlig fortelletradisjon, sheeko xarir. ${ }^{5}$ Hun beskriver seg selv som «litt nasjonalist», og oppdaterer seg på somalisk historie og kultur giennom internettsider drevet av somaliere verden over.

I likhet med Najma bruker Fawzia youtube mye. Drama og sitcom-komedier på somalisk, ruwayyad, gir avkobling når hun trenger å "glemme», som hun uttrykker det. Fawzia forklarer at hun ofte bruker tonesatte dikt, heelloy, til å trøste seg selv, særlig når hun lengter etter mora, som fortsatt bor i Somalia. Fawzia har ikke sett henne på over tjue år:

Det er veldig vanskelig, når du er borte fra familien din, lenge lenge lenge. Når jeg var barn - jeg var barn når jeg reiste fra Somalia. Veldig veldig vondt for meg. $\mathrm{Da} . .$. mora mi sier: Ikke tenke på, du bor i annet land! Du må tenke framtida di! Sånn som en person, støtter på meg hele tida. (Fawzia, 36, Somalia)

\footnotetext{
${ }^{5}$ Hun nevner for eksempel kjente karakterer som Cigaal Shidaad, Dheg Dheer, Wiil Waal og Carawelo.
} 


\section{Anundsen}

Det tyngste er å ikke vite om hun noen gang får se sin mor igjen, sier Fawzia. Derfor er det særlig sanglyrikk som uttrykker kjærlighet til og savn av hooyo (mor) hun hører på når hun trenger trøst. På youtube fins en rekke slike sanger som Fawzia jevnlig hører på. I tekstene artikuleres noe av hennes egen kjærlighet og savn. Et utdrag fra en av sangtekstene oversetter hun slik: ${ }^{6}$

Hooyo, ikke vær lei deg/Du kan ikke være død for meg/Du er øyet mitt/Du er halvdelen av meg/Du er aldri død for meg.

I likhet med Najma oppsøker altså Fawzia aktivt litterære uttrykk på youtube - i dette tilfellet dikt, sanglyrikk og drama - som kan dekke et behov for avkobling eller trøst. Men Fawzia leser også bøker av og til. Disse leser hun på norsk. Hun er en av informantene som har bodd lengst i Norge (seks år), så språket representerer relativt sett et mindre problem for henne. De delvis selvbiografiske debattbøkene til Amal Aden er Fawzias favoritter. Adens skarpe kritikk av ukultur i enkelte norsksomaliske miljøer gjør henne omstridt, men Fawzia er begeistret: «Jeg leser hun, jeg liker henne, bøker fra henne støtter på meg. Ja.» Aden skriver om frihet til å velge hvordan du kan leve «når du ønsker å gjøre noe», forklarer Fawzia. Adens bøker har med andre ord en støttende funksjon. Denne kaller jeg "agency», forstått som opplevd handlingsrom i en gitt situasjon. For å forklare hvordan Adens bøker støtter henne» forteller Fawzia en selvopplevd episode: Selv bruker hun ikke den mest heldekkende typen hijab som er vanlig blant mange somaliske kvinner, men en annen, mindre dekkende variant. Enkelte innen det somaliske miljøet ser ned på henne for dette. Men, sier Fawzia: «Jeg bestemmer sjøl hva jeg bruker!» Hun posisjonerer seg med andre ord som en som tør å utfordre konvensjoner:

Ja, jeg ikke være redd! De sier, hun her, hun er sterk og hun ikke være redd. Hun svarer på deg. Jeg ikke være redd! For jeg sier: Jeg kommer hit, og jeg er voksen person, og jeg bestemmer sjøl. Du ikke være mora min eller familien min. Ikke glemme den! Du må respektere på meg, hva jeg vil! Jeg svarer! [ler] (Fawzia, 36, Somalia)

Fawzias protest mot sosial kontroll er å fortsette med sin variant av hijab og ignorere eventuelle misbilligende blikk. Hun demonstrerer agency, om enn på mikronivå. Selv om hun framstiller seg selv som uredd og selvbevisst, er hun tydelig på at hun trenger den moralske støtten fra Aden - bøkene bekrefter det legitime i å insistere på selvstendighet og handlingsrom.

Hva gjør de litterære tekstpraksisene for informantene? Ved å stille dette spørsmålet trer ulike funksjoner fram: emosjonell støtte eller påfyll (Najma: gabay), trøst

\footnotetext{
${ }^{6}$ Fawzias oversettelse har blitt bearbeidet til en mer sammenhengende tekst av meg. Faisal Aligas oversetter den samme teksten (på min forespørsmål) noe annerledes: «Mamma, jeg er del av din kropp/Jeg elsker deg, Mamma/Tilværelsen viser din storhet/Du er skapt av stammen som ikke kan knekkes ... Du er det mest verdifulle mennesket/Ingen kan noensinne leve uten deg». Takk til Faisal for oversettelse.
} 
(Fawzia: heelloy, sanglyrikk), avkobling (Fawzia: ruwaayad, drama/komedie), agency eller støtte til agency (Fawzia: Adens bøker, Noor: gabay), samt kulturell tilhørighet og identitet (Noor: gabay og internettekster).

De somaliske informantenes litterære repertoar er framfor alt preget av muntlige litterære tradisjoner, særlig fortellinger (sheeko) og ulike poetiske sjangre (gabay, heelloy, buraambur). Poesi omtales som en tilgjengelig ressurs og er ikke reservert en kunstnerisk elite; informantene har enten slektninger som lager egne gabay (Najma, Fawzia), eller lager selv gabay (Noor). De litterære tekstene informantene refererer til i sin nåværende praksis er primært digitalt og audiovisuelt mediert, og youtubevideoer er særlig framtredende. Trykte, papirbaserte tekster blir lite omtalt, og da på norsk, ikke somalisk. Overgangen fra primært muntlige tekstpraksiser i somalisk kontekst til nye tekstpraksiser i Norge går altså utenom trykte tekster, men i stedet via youtube og andre digitale tekstplattformer.

\section{Litterære tekstpraksiser hos de syriske informantene}

Den litterære teksttypen som er mest framtredende i dataene fra de syriske informantene, er dikt eller poesi, shaear. Shaear brukes som fellesnevner for dikt generelt, selv om en informant (Walid) også nevner qasida, som i engelsk oversettelse gjerne sammenlignes med oden (Starkey, 2006, s. 11). Det er særlig to av de fem syriske informantene som uttrykker aktiv bruk av shaear: Sami (se innledningssitat) og Ibrahim. Sami forteller at han har hørt eller lest shaear daglig i mange år gjennom radio, opplesninger eller i bøker. Poesi er det suverent mest utbredte og populære litterære uttrykket i den arabiskspråklige verden, noe som illustreres gjennom de enorme seertallene til poesikonkurranser på tv. ${ }^{7}$ Paul Starkey konstaterer at "poetry in the Middle East ... enjoys an esteem seldom paralleled in the West» (Starkey, 2006, s. 199). Gitt denne posisjonen er det rimelig å anta at shaear også er en sentral del av skolens tekstpraksis. Dette kommer imidlertid ikke så klart fram av intervju med informantene, som har mellom syv og ni års grunnskole. Ibrahim (24) forklarer ${ }^{8}$ at han aldri har vært "særlig interessert i lesing eller skole». Men han hører ofte på dikt:

Jeg pleier å høre på de [dikt], eller se på de som regel. På youtube. Gamle, men nye også. ... Ford; det er litt - følelsesrikt, det er trist, men sånn dramatisk følelsesrikt, men også vakkert liksom. (Ibrahim, 24, Syria)

Det at diktet oppleves som «vakkert» og «følelsesrikt» er det Ibrahim forklarer som den viktigste grunnen for å høre på dikt; altså diktet som estetisk erfaring (Rosenblatt, 1978/1994). Ut over dette utdyper han ikke hva det betyr for ham. På spørsmål om han husker «litteratur» eller litterære tekster fra skolen, svarer Ibrahim med å beskrive skolefaget, ikke tekstene:

\footnotetext{
${ }^{7}$ For informasjon om Million's Poet, se for eksempel https://en.wikipedia.org/wiki/Million\%27s_Poet

${ }^{8}$ I intervjuet med Ibrahim ble det brukt arabisk tolk.
} 


\section{Anundsen}

Vi hadde den - det heter uttrykksfaget, og det faget er en del av faget i arabisk, litteratur, og det handler om å kunne uttrykke seg, og vi lærte blant annet om livet, og respekt, og sånn. (Ibrahim, 24, Syria)

Det norske ordet «skjønnlitteratur» oversettes til arabisk med adab. Men som det framgår av sitatet, snakker Ibrahim her om noe mer og annet enn litterære tekster. Starkey forklarer $a d a b$ som " $\ldots$ a considerably more complex term that embraces, in addition to literature, 'culture', 'good manners', decency' and 'humanity'" (Starkey, 2006, s. X). Adab kan altså minne om vårt dannelsesbegrep. Hvilken plass litterære tekster har i skolens formidling av adab kommenteres sparsomt av informantene. At Ibrahim jevnlig hører (eller ser) shaear på youtube, er tydelig en individuell litterær tekstpraksis han ikke relaterer til skolen.

Sami (31) har som nevnt pleid å høre og lese shaear på egen hånd i mange år. Den klassiske 900-tallsdikteren al-Mutanabbi er en av favorittene. Underveis i intervjuet siterer han spontant fra flere dikt, b åde av a l-Mutanabbi og Nizar Q abbani, e $n$ annen favorittdikter. Qabbanis hus i Damaskus vet han godt hvor ligger. De syriske informantene trekker fram at "alle» i Syria kjenner diktene til Qabbani. (Diana, Sami, Ibrahim. Starkey beskriver Qabbani som «almost certainly the most popular of contemporary Arabic poets» (Starkey, 2006). Særlig kjærlighetsdiktene har et stort publikum, ikke minst fordi de ofte framføres som populærmusikk av kjente artister. Sami er den eneste av informantene som også framhever Qabbanis poli-tiske, regimekritiske dikt. Diktene førte til at forfatterskapet ble sensurert $\mathrm{i}$ flere arabiske land (Gohar, 2011) og har derfor ikke vært like tilgjengelige som kjærlig-hetsdiktene. Men Sami kjenner dem, og siterer utenat en passasje fra diktet Antara, som han forklarer inneholder skarp kritikk av Assadregimet. Tittelen refererer til en kjent helteskikkelse fra arabisk folklore, Antar, som forsvarte sin egen stamme mot invasjon fra inntrengere (Gohar, 2011). I diktet kritiserer Qabbani den "moderne» Antar, en metafor for samtidas arabiske politiske ledere, for å ha fjernet seg fra folket og «...sold his homeland to the enemies» (Gohar, 2011, s. 104). Ifølge Sami er kritikken i diktet like gyldig overfor dagens regime, selv om Qabbani selv døde i 1998: «Og han, Nizar Qabbani, han liker - Hafez Assad, Bashar al-Assad - liker ikke!» For Sami har disse diktene betydning ut over den estetiske opplevelsen. Gjen-nom Antara artikuleres en kritikk som ellers har vært umulig å uttrykke åpent i det totalitære syriske samfunnet. Ved å gi sin anerkjennelse av og tilslutning til diktene tilkjennegir han også sin egen kritiske holdning til regimet.

På spørsmål om han husker noen fortellinger fra oppveksten, svarer Sami kontant at han «ikke liker» fortellinger. Dette begrunner han med et eksempel fra skolens tekstpraksis:

Fortelling. Ja. Har ikke frihet i fortelling. Bare, eksempel: «Hafez Assad gjøre den, den den». Bare fortelle til ham! Ja. ... Eksempel, på skole - første år på skole i Syria, alle bok har bilde til han. Også, skrive med han. Han gjøre ting, han gjør sykehus, han gjør skole, han gjøre han gjøre han gjøre ... det ... kjedelig! (Sami, 31, Syria) 
Sami avviser «fortelling» som sjanger ut fra sin erfaring med det syriske regimets propagandaapparat, som han tydelig kobler til skolens tekstpraksis. Teksttypen han beskriver kan knapt kalles en "egentlig» fortelling, snarere en blanding av sakprosa og heltefortelling, med tydelig didaktiske og retoriske trekk. Hvordan Sami eventuelt ville stille seg til litterært sett mer komplekse, potensielt kritiske eller subversive fortellinger gir datamaterialet ikke grunnlag for å si noe om.

Diana (23) liker fortellinger, sier hun, men å lese bøker er «kjedelig». Hun foretrekker "sanne fortellinger», noe hun forklarer som fortellinger om «folk som har problemer.» Når hun føler seg alene er drama, særlig tv-serier og filmer om "hva som har skjedd med mennesker», det som hjelper henne. Trøst i form av gjenkjennelse eller skjebnefellesskap ser ut til å være en funksjon ved Dianas litterære tekstpraksis. Hun uttrykker imidlertid også ambivalens til hvorvidt denne typen filmer egentlig er bra for henne. For:

Jeg føler at det skjer nå, med meg. Det skjer nå. Jeg husker alt med en gang når jeg ser sånn film, av og til jeg bare gråter når jeg ser sånn film. (Diana, 23, Syria)

Dianas tekstpraksis har et element av repetert lidelse. Men tross alt vokser det fram et behov for å gå videre: «Men av og til, når jeg ser på romantic film, jeg tenker at livet ikke stopper, livet fortsetter og jeg må klatre, eller fortsette igjen.»

Fortellende tekster, både skriftlige og muntlige, blir ellers lite omtalt av de syriske informantene. Riwaya, romaner, blir ikke nevnt, og Syrias muntlige fortellerkultur (Tahhan, 2004) er lite synlig i materialet. Innenfor arabisk litterær tradisjonen er $a d a b$, «litteratur», avgrenset til å gjelde verk skrevet og/eller framført på klassisk arabisk, og folkelige sjangre formidlet på muntlige dialekter blir knapt tilkjent status som «litteratur» overhodet (Starkey, 2006). Hiba (32) nevner imidlertid hikaya, eventyr/ fortelling, enten fortalt muntlig eller via bøker og film til egne barn. Walid (45) leser daglig norske bildebøker han låner på biblioteket for sine egne barn. Høytlesning begynte han med etter at han kom til Norge. Hiba og Walid er de eneste av de syriske informantene som er foreldre, og tekstpraksisene deres er knyttet til oppdragelse og omsorg innenfor hjemmets og familiens domene.

Poesi eller shaear framstår som en sentral sjanger i de syriske informantenes litterære repertoar, og dessuten i to av informantenes aktive tekstpraksiser (Ibrahim, Sami), hvor shaear forekommer i ulike medieringer, ikke minst som audiovisuelle tekster på youtube. Andre teksttyper informantene bruker jevnlig er filmdrama (Diana) samt hikaya (eventyr, fortellinger) og bildebøker (Hiba, Walid), mens lengre, fortellende litterære tekster i trykte, papirbaserte versjoner (som romaner) ikke ser ut til å inngå verken i informantenes aktive tekstpraksiser eller deres litterære repertoar. Samis kommentar til regimestøttende tekstpraksis i syrisk skole tyder på at propagandapregede tekster er velkjent for syrere flest, og sannsynligvis del av deres allmenne og litterære repertoar.

I de syriske informantenes tekstpraksiser identifiserer jeg funksjonene estetisk nytelse (Ibrahim, Sami: shaear) posisjonering eller agency (Sami: Qabbanis dikt), 


\section{Anundsen}

gjenkjennelse og trøst (Diana: filmdrama), omsorg og oppdragelse (Hiba, Walid: hikaya, bildebøker) samt kulturell tilhørighet (Sami, Ibrahim: shaear, Hiba: hikaya).

\section{Litterære tekstpraksiser hos de eritreiske informantene}

De ni eritreiske informantene utgjør den største av de tre gruppene. Skolebakgrunnen varierer mellom fire (1), syv - ni (6) og elleve eller tolv års skolegang (2). I denne gruppa er fortellinger, på tigrinja ${ }^{9}$ tsntsway, den klart mest omtalte litterære teksttypen, og nevnes av samtlige. Tsntsway brukes tilsynelatende som en samlebetegnelse på alle kortere, fortellende tekster med plot eller fiktive trekk. Først og fremst hører tsntsway til den muntlige litterære kulturen:

I min kultur, bare muntlig - eventyr, til barna eller til voksne, bare muntlig. ...

Bestefar og bestemor forteller, kjempegøy, kjempe. (Semhar, 34, Eritrea)

Tsntsway kan altså være underholdende fortellinger for både barn og voksne. Et eksempel er historiene om $\mathrm{Abu}$ Gebrehane, som utelukkende formidles muntlig og er kjent av «alle» (Helen, Mebratu, Tesfay). I ulike situasjoner opptrer "Gamlefar Gebrehane» klokt, dumt, eller kanskje framfor alt overraskende, noe som fører til komikk og en humoristisk vending. Disse morsomme småstubbene illustrerer ofte et poeng, ifølge Mebratu: ${ }^{10}$

Det er sånn at foreldre forteller deg, at de lærer deg om livet, i virkeligheten. Litt budskap, og veldig morsomt samtidig. (Mebratu, 23, Eritrea)

I sin doktoravhandling om norske og eritreiske studenter bekrefter Juliet Munden (Munden, 2010) indirekte Mebratus eksempel. Den sterke posisjonen muntlige fortellinger fortsatt ser ut til å ha i Eritrea kommenteres med at «... oral tradition provides both entertainment and cultural and moral instruction" (Munden, 2010, s. 172). Hovedinntrykket fra informantene er at tsntsway ofte har fabellignende trekk, noe som kjennetegner mye tradisjonell afrikansk fortellekunst (Finnegan, 1976). Siden fabelen både underholder og oppdrar, egner den seg godt til didaktisk bruk. Flere av informantene forteller da også at tsntsway, for eksempel moralske fortellinger om "en flink og en dårlig elev» (Ngesti), ble brukt både i muntlige og skriftlige versjoner på småskoletrinnet (Tekle, Ngesti, Edom, Fiori). Fra sjette skoletrinn er engelsk undervisningsspråk i samtlige fag i Eritrea (Asfaha, 2009), til tross for at de færreste elevene behersker språket særlig godt (Semhar, Edom, Ngesti, Mebratu, Estefanos, Tesfay). Med ett unntak ${ }^{11}$ nevner ingen informanter konkrete eksempler på litterære tekster fra disse skoleårene.

Lengre, skriftlige fortellinger, libweled (skriftlig fortelling, fiksjon, roman), blir lite omtalt. Ifølge Edom (34) hadde han som voksen sjelden tid til å lese libweled. Under den omfattende militærtjenesten, som han i likhet med mange eritreere har bak seg,

\footnotetext{
${ }^{9}$ Eritrea har flere ulike språkgrupper. I mitt materiale var tigrinja førstespråk for alle intervjupersonene.

${ }^{10}$ Intervjuet med Mebratu ble gjennomført med tospråklig lærer som tolk.

${ }^{11}$ Lesebokutdrag fra Dickens-klassikeren Oliver Twist, om da Oliver ba om å få mer suppe (Helen).
} 
var det dessuten ikke lov. ${ }^{12}$ Semhar (33) forklarer at hun leste libweled iblant, men ikke ofte. I grunnskoleklassen har hun imidlertid nylig lest en norsk roman som har gjort sterkt inntrykk på henne:Veronica Salinas’ Og (Salinas, 2016), om en ung argentinsk kvinne som kommer til Norge som au pair. Semhar gjenkjenner egne migrasjonserfaringer i romanen, og er så begeistret at hun vurderer å lese den for dattera på sju. Romanen kan brukes for å forklare flukten fra hjemlandet, sier hun, et samtaleemne hun hittil har unngått. $O g$ består av en rekke korte, dels introspektive tekster fra vekselvis Norge og Argentina, og det er vanskelig å se for seg at boka vil appellere til en sjuåring. At Semhar vurderer det er på den ene siden et tydelig tegn på at romanen har betydd noe for henne. At hun ikke reflekterer over muligheten for å finne en mer alderstilpasset tekst, forteller på den andre siden om et litterært repertoar der didaktisk bruk av fortellinger er velkjent, mens erfaring med og tilgang til skriftbaserte barnelitterære tekster er begrenset.

Andre litterære sjangre som nevnes av de eritreiske informantene, er gtemi, dikt, og mezmur, sang, særlig liturgisk lovsang brukt i gudstjenester. Flere av informantene er tilknyttet lokale eritreisk-ortodokse menighetsfellesskap i Norge (Semhar, Fiori, Ngesti), og mezmur, knyttet til det liturgiske språket/skriftsystemet $g e^{\prime} e z,{ }^{13}$ har fulgt informantene fra Eritrea videre inn i deres nye liv i Norge. I det samlede datamaterialet er det for øvrig kun eritreiske informanter som nevner bøker på eget språk hjemme (Estefanos, Semhar, Edom, Fiori, Ngesti). ${ }^{14}$

Gtemi, dikt, omtales i tilknytning til ulike domener i hjemlandet: på skolen (Semhar, Edom, Estefanos), som kjærlighetsdikt for personlig lesning (Mebratu), og som del av en nasjonal (nasjonalistisk) kultur (Edom, Estefanos). Estefanos (38) forteller at det ofte var gtemi på radioen, og de handlet som regel om «krigen, om kultur». Litteraturforskeren Christine Matzke fastslår at "[d] iscourses of war have pervaded all cultural expressions in Eritrea»(Matzke, 2003, s. 151). Særlig i perioden 1970-1991 har frigjøringskrigen mot Etiopia vært tematisert både i dikt (Cantalupo, 2009; Negash, 1999) og drama; Matzke omtaler den som "the prime motif in the performing arts» (Matzke, 2003, s. 152). Edom (34) beskriver framføring av nasjonalistiske dikt i offisielle markeringer av Eritreas nasjonaldag 24. mai, der presidenten stiller med militærparader og taler:

Han [presidenten, min anm.] kommer, og - [jeg] bare ser på tv - og han snakker med alle elevene, og etterpå den, noen kommer og tar som gtemi, litt fortelle, om independence og som Etiopia, og som krig, og sånn, sånn. (Edom, 34, Eritrea)

\footnotetext{
${ }^{12}$ Militærtjeneste (National Service) er obligatorisk i Eritrea, og varer gjerne på ubestemt tid. Blant eritreerne som deltok i denne studien (ni personer i alderen 20 til 38 år) hadde de tre yngste flyktet like etter avsluttet grunnskole, og dermed unngått militærtjeneste. Intervjupersonene mellom 26 og 38 år hadde gjennomført militærtjeneste, med varighet fra fem til tolv år.

${ }^{13}$ Ge'ez som talespråk er utdødd, men brukes som liturgisk språk i Etiopia og Eritrea, og som betegnelse på skriftsystemet i amharisk og tigrinja (Negash, 1999).

${ }^{14}$ Bøkene som omtales er, i tillegg til Bibelen, ei bokstavlæringsbok på tigrinja for barn, ei kokebok, illustrert ordbok norsk-tigrinja og to historie/fortellingsbøker.
} 


\section{Anundsen}

Framføring av gtemi om frigjøringskampen er altså del av en offisiell litterær tekstpraksis, en «regimepraksis» med symbolske funksjoner: Feiringen bidrar til å begrunne nødvendigheten av en omfattende militærtjeneste og ikke minst bekrefte det sittende regimets posisjon. Edom understreker at han bare har sett disse markeringene på tv. Å gå dit selv (og dermed indirekte legitimere regimet) kunne han overhodet ikke tenke seg, sier han: «Aldri!»

Estefanos (38) er den eneste som oppgir at han fortsatt leser gtemi iblant. Diktene gir ham «informasjon», forklarer han, og Facebook varsler om nye publiseringer på webforum eller youtube. Muligens har diktene en form for kommentarfunksjon, for eksempel til den politiske situasjonen i Eritrea, men datamaterialet gir ikke grunnlag for å si noe sikkert om dette. Men Estefanos' gtemi-praksis på sosiale medier synliggiør et diasporafellesskap; diktene inngår i strømmen av oppdateringer og erfaringsutvekslinger som forbinder eritreere i eksil med hverandre.

Sentralt i de eritreiske informantenes litterære repertoarer er altså muntlige fortellinger, tsntsway, ofte med en didaktisk funksjon. Tsntsway ser imidlertid ut til å være en tilbakelagt tekstpraksis for de fleste, noe som kan henge sammen med at flertallet av informantene ikke har (små) barn. Dermed blir mange av tsntsway-praksisens funksjoner, som oppdragelse og tradisjonsformidling, mindre aktuelle. Semhars ønske om å lese $O g$ for dattera kan imidlertid forklares ved å se fortellingers didaktiske funksjon som framtredende i hennes litterære repertoar. Også Edoms beskrivelse av gtemi $\mathrm{i}$ en nasjonalistisk regimepraksis viser litterære tekster (her: poetiske) brukt didaktisk eller instrumentelt, men i dette tilfelle er konteksten ikke familien, men den totalitære ettpartistaten. Kulturell og religiøs tilhørighet (Ngesti, Fiori, m.fl.: mezmur) og deltakelse i diasporafellesskap (Estefanos: gtemi) er andre funksjoner som trer fram som mulige svar på spørsmålet om hva de individuelle litterære tekstpraksisene giør for de eritreiske informantene.

\section{Oppsummering}

Analysen av datamaterialet identifiserer en rekke aktive litterære tekstpraksiser, altså en regelmessig bruk av litterære uttrykk i ulike medieringer. At de somaliske informantene har klart minst skolegang innad i informantgruppa, men samtidig er blant informantene med de mest aktive litterære tekstpraksisene, er en påminnelse om at litteratur og litterære erfaringer ikke er fenomener som primært hører til skolens domene. At de fleste tekstpraksisene nettopp forekommer utenfor skolen, betyr imidlertid mest sannsynlig at de vil oppleves som «skjult» (Nergård \& Nicolaisen, 2016) i skolehverdagen. Litteraturbegrepet i grunnskolen er i all hovedsak festet til skrift, mens vi har sett at informantenes litterære repertoarer særlig er preget av muntlige litterære tradisjoner og teksttyper. Romansjangeren, sentral i europeisk tradisjon og formodentlig del av grunnskolelærernes litterære repertoar, utgiør en ubetydelig del av informantenes erfaringer med litterær tekst, mens poetiske sjangre og muntlige fortellinger er langt mer framtredende.

Studien viser at migrasjonen medfører et skifte i mediering av teksttyper for en del informanter. Flertallet av de aktive litterære tekstpraksisene er sentrert rundt digitale 
eller audiovisuelle tekster, der youtube er det viktigste mediet. Svært få informanter leser papirbaserte litterære tekster på eget språk (eller norsk) hjemme. PC og smarttelefon ${ }^{15}$ gir enkel tilgang til tekster på eget språk, og forklarer delvis youtubes sentrale rolle i flere tekstpraksiser. Men ikke minst inkorporerer denne litterære hybriden auditive og performative elementer fra muntlig-litterære tradisjoner, som det å kunne se og høre oppleseren. En diktvideo kan bestå av en filmet framføring der publikum er synlig og hørbart til stede, eller av bilder eller film med skriftlig verbaltekst. Den kan ha skjult eller synlig oppleser, og være med eller uten bakgrunnsmusikk. Det multimodale youtube-diktets litterære repertoar «matcher» (McCormick, 1994) dermed trolig mange informanters litterære repertoarer bedre enn hva en trykt, papirbasert diktversjon vil giøre. Tekstpraksiser sentrert rundt sosiale medier tilbyr også deltakelse i et diaspora-fellesskap på tvers av landegrenser. Flere av informantenes litterære tekstpraksiser foregår innenfor denne typen globale tekstarenaer, der de også tilbys tilknytning til og deltakelse i språklige og kulturelle fellesskap. Praksisene befinner seg i overganger mellom vidt forskjellige kontekster; overganger som kan innebære både brudd, kontinuitet og ny praksis. Tilgang og funksjon framstår som sentrale forklaringer på hvorfor praksiser henholdsvis avsluttes, videreføres eller transformeres: Hvilke tekster og medieringer informantene bruker, styres dels av tilgang til og distribusjon av teksttyper, dels av hvilke funksjoner tekstene er knyttet til og hva tekstpraksisene "giør» for informantene. Her trer det fram et kontinuum av ulike funksjoner: trøst, emosjonell støtte, påfyll (Najma, Fawzia, Diana), estetisk opplevelse/ nytelse (Ibrahim, Sami), gjenkjennelse og innsikt (Diana, Semhar) avkobling (Fawzia) kulturell/ religiøs tilhørighet og identitet (Noor, Ngesti, Fiori) deltakelse i global, digital tekstverden/ diasporafellesskap (Estefanos, Noor, Najma, Fawzia, Ibrahim, Sami) posisjonering og agency (Sami, Fawzia, Noor), oppdragelse og omsorg (Hiba, Walid, Semhar). Funksjonene lest som et kontinuum viser seg å være mer eller mindre innadrettede eller utadrettede: Eksempelvis har trøst primært en innadrettet eller «intern» funksjon, mens funksjoner som agency, oppdragelse og deltakelse i diasporafellesskap i større grad dreier seg om handling overfor eller samhandling med andre, og representerer mer utadrettede eller "eksterne» funksjoner. Å se funksjonene som et kontinuum synliggjør hvor mange områder av livet disse tekstpraksisene inngår i; fra de dypt personlige eller private til de mer allmenne og offentlige.

\section{Diskusjon}

Et spørsmål i forlengelse av studien er: Hvordan legge til rette for overganger mellom tekstpraksiser, overganger som bidrar til at informantene/elevene lykkes i utdanninga? En nærliggende implikasjon er at framtidig undervisning bør flyttes nærmere elevenes bakgrunn. Litteraturundervisning i grunnskoleløp for

\footnotetext{
${ }^{15}$ I hvilken grad informantene har hatt tilgang til dette tidligere har jeg ikke oversikt over, men jeg vet at flere fikk pc og/eller smarttelefon første gang i Norge.
} 


\section{Anundsen}

voksne bør ta utgangspunkt i elevenes forforståelse og erfaring - deres litterære repertoarer.

I studien omtales bare én konkret leseopplevelse fra skolesammenheng, nemlig Semhars møte med romanen $O g$ (Salinas, 2016). Analysens fokus på litterære tekstpraksisers funksjoner argumenterer imidlertid for at også teksterfaringer og praksiser utenfor skolens kontekst kan inneholde kunnskap om og aktivt fortolkende bruk av litterære tekster. Dette gjelder uavhengig av om teksten er et dikt, en roman, en sang eller en film. Dermed kan det være på sin plass, også i skolesammenheng, å vise interesse for og anerkjenne ulike litterære tekstpraksiser som relevant erfaring med litteratur.

\section{Nye litteraturer: endring av territoriet}

Innledningsvis argumenterte jeg for å se litteraturfeltet som et diskursivt felt, et "territory» (Masny, 2013) der visse oppfatninger, konvensjoner og verdier er gjeldende. Litteraturbegrepet i vestlig tradisjon, norsk skole inkludert, er i stor grad festet til skrift, og våre forventninger til litteratur og kjennskap til litterære sjangre er naturlig nok preget av nordisk og europeisk litteraturhistorie. Andre deler av verden har andre litteraturer, men så lenge disse ikke er del av vårt kjente "territorium», vil erfaringer med bakgrunn herfra ofte framstå som usynlige eller uvesentlige. Hva må skje med «territoriet» i norske klasserom, hvordan vi oppfatter, snakker om og praktiserer litteratur, for at elever som har bakgrunn fra andre «territorier» kan ha nytte av sin kunnskap og sine erfaringer derfra? Artikkelens intensjon har vært å skrive fram en form for «brudd" giennom å synliggiøre og peke på relevansen av andre litteraturer og av ikke-institusjonelle litterære tekstpraksiser. Territoriet endres, "reterritorialiseres», når fokus forflyttes. I A lese verden (Vold, 2019) viser Tonje Vold til den nederlandske litteraturforskeren Mineke Schippers' undersøkelse av litterære fenomener på tvers av ulike kulturer. Schippers peker på at «når forskeren beveger seg vekk fra det vestlige som fokuspunkt, forskyves også de etablerte oppfatningene av hva litteratur og litteraritet er» (Vold, 2019, s. 362). Med andre ord; territoriet endrer seg. Et mer globalt informert litteraturbegrep kan berike både grunnskole og litteraturfag. Det kan bidra til at migranters erfaring verdsettes høyere, men også tilby en vitalisering av litteraturbegrepet som sådan. Sist, men ikke minst, ligger kimen til en produktiv fornying av litteraturfeltet i en tilnærming til litteratur ikke bare som tekst, men som praksis: Hva betyr litteraturen for oss; hvilke funksjoner har den? Hva gjør vi med den - og hva gjør den med oss? Gjennom å utforske og utfordres av denne typen spørsmål kan litteraturfeltet fornyes og utvides som fellesskap, og litteraturundervisninga vil kunne angå flere.

\section{Forfatteromtale}

Lene Anundsen (f.1968) er stipendiat i litteraturdidaktikk ved Universitetet i Agder. I sitt ph.d.-prosjekt undersøker hun litteraturundervisning i grunnskoletilbud 
for voksne, minoritetsspråklige elever, med særlig interesse for litteraturerfaringer og tekstpraksis hos deltakerne. Anundsen har tidligere arbeidet med norskopplæring for voksne innvandrere.

\section{Referanser}

Alvesson, M. \& Sköldberg, K. (2008). Tolkning och reflektion: vetenskapsfilosofi och kvalitativ metod (2. utg.). Lund: Studentlitteratur.

Andrzejewski, B. W. (2011a). Alliteration and scansion in Somali oral poetry and their cultural correlates. Fournal of African Cultural Studies, 23(1), 37-47. https://doi.org/10.1080/13696815.2011.581456

Andrzejewski, B.W. (2011b). The literary culture of the Somali people. Fournal of African Cultural Studies, 23(1), 9-17. https://doi.org/10.1080/13696815.2011.581452

Asfaha, Y. M. (2009). English literacy in schools and public places in multilingual Eritrea. I I. van de Craats \& J. Kurvers (Red.), Low-educated adult second language and literacy acquisition (s. 213-221). Utrecht: LOT Netherlands Graduate School of Linguistics.

Bakhtin, M. (1998). Spørsmålet om talegenrane (R. Slaattelid, Overs.). Bergen: Ariadne forlag.

Barton, D. \& Hamilton, M. (1998). Local literacies: reading and writing in one community. London: Routledge.

Barton, D., Hamilton, M. \& Ivanič, R. (2000). Situated literacies: reading and writing in context. London: Routledge.

Blackledge, A. (2000). Power Relations and the Social Construction of 'Literacy' and 'Illiteracy': The Experience of Bangladeshi Women in Birmingham. I M. Martin-Jones \& K. Jones (Red.), Multilingual Literacies: Reading and Writing Different Worlds (s. 55-69). Amsterdam: John Benjamins Publishing.

Cantalupo, C. (2009). War and peace in contemporary Eritrean poetry. Oxford: African Books Collective.

Dewilde, J. (2017). Multilingual Young People as Writers in a Global Age. I B. Paulsrud, J. Rosén, B. Straszer \& A. Wedin (Red.), New Perspectives on Translanguaging and Education (s. 56-71). Bristol: Multilingual Matters.

Dewilde, J. \& Skrefsrud, T.-A. (2016). Including alternative stories in the mainstream. How transcultural young people in Norway perform creative cultural resistance in and outside of school. International fournal of Inclusive Education, 20(10), 1032-1042. https://doi.org/10.1080/13603116.2016.1145263

Dewilde, J. (2018). "It's just in my heart": a portrait of a translingual young person as a writer of poetry. IT. O. Engen, L. A. Kulbrandstad \& S. Lied (Red.), Norwegian perspectives on education and diversity (s. 103-120). Newcastle upon Tyne: Cambridge Scholars Publishing.

Dæhlen, M., Danielsen, K., Strandbu, Å. \& Seippel, Ø. Voksne i grunnskole og videregående opplæring (NOVA Rapport 7/2013). Hentet fra http:/www.hioa.no/content/download/45477/674738/file/6820_1.pdf

Economou, C. (2016). "I svenska två vågar jag prata mer och så": en didaktisk studie om skolämnet svenska som andraspråk. (Doktoravhandling, Göteborgs universitet, Sverige). Hentet fra http://hdl.handle.net/ $2077 / 39343$

Finnegan, R. (1976). Oral literature in Africa. Nairobi: Oxford University Press.

Gee, J. P. (2015). Literacy and education. New York: Routledge.

Gohar, S. M. (2011). Re-historicizing the Six-Day War:The Counter-Poetics of Nizar Qabbani. SKASE fournal of Literary Studies, 3(1), 97-116. Hentet fra http://www.skase.sk/Volumes/JLS03/pdf_doc/06.pdf

Gregory, E. \& Williams, A. (2000). Work or Play? 'Unofficial' Literacies in the Lives of Two East London Communities. I M. Martin-Jones \& K. Jones (Red.), Multilingual Literacies: Reading and Writing Different Worlds (s. 37-54). Amsterdam: John Benjamins Publishing.

Heath, S. B. (1983). Ways with words: language, life, and work in communities and classrooms. Cambridge: Cambridge University Press.

Hoehne, M. V. \& Luling, V. (2010). Milk and peace, drought and war: Somali culture, society and politics: essays in honour of I. M. Lewis. London: Hurst \& Company.

Hvistendahl, R. (2000). "Så langt 'vår' diktning tenner sinn i brann-": en studie av fire minoritetsspråklige elevers arbeid med norsk litteratur fra perioden 1860-1900 (Doktoravhandling). Universitetet i Oslo, Oslo.

Kjelen, H. A. (2013). Litteraturundervisning i ungdomsskulen: kanon, danning og kompetanse (Doktoravhandling, Norges teknisk-naturvitenskapelige universitet). Hentet fra http://hdl.handle.net/11250/244244

Kvale, S. \& Brinkmann, S. (2015). Det kvalitative forskningsintervju (3. utg.). Oslo: Gyldendal akademisk.

Lidén, H. (2001). Underforstått likhet: skolens håndtering av forskjeller i et flerkulturelt samfunn. I M. Lien, H. Lidén, \& H. Vike (Red.), Likhetens paradokser. Antropologiske undersøkelser $i$ det moderne Norge (s. 68-85). Oslo: Universitetsforlaget. 


\section{Anundsen}

Martin-Jones, M. \& Jones, K. (2000). Multilingual Literacies: Reading and Writing Different Worlds. Amsterdam: John Benjamins Publishing.

Masny, D. (2010). Multiple Literacies Theory: how it functions, what it produces. Perspectiva, 28(2), 337-352. https://doi.org/10.5007/2175-795X.2010v28n2p337

Masny, D. (2013). Rhizoanalytic Pathways in Qualitative Research. Qualitative Inquiry, 19(5), 339-348. https:// doi.org/10.1177/1077800413479559

Masny, D. \& Cole, D. R. (Red.). (2009). Multiple Literacies Theory: A Deleuzian Perspective. Rotterdam: Sense Publishers.

Matzke, C. (2003). En-gendering theatre in Eritrea: the roles and representations of women in the performing arts: (Doktoravhandling, The University of Leeds). Hentet fra http://etheses.whiterose.ac.uk/id/eprint/796

McCormick, K. (1994). The culture of reading and the teaching of English. Manchester: Manchester University Press.

Molloy, G. (2002). Läraren, litteraturen, eleven:en studie om läsning av skönlitteratur på högstadiet (Doktoravhandling, Stockholms universitet, Sverige). Hentet fra oai:DiVA.org:su-148355

Munden, J. (2010). How students in Eritrea and Norway make sense of literature Doktoravhandling, Universitetet i Oslo). Hentet fra http://hdl.handle.net/11250/132010

Negash, G. (1999). A history of Tigrinya literature in Eritrea: the oral and written 1890-1991. Leiden: Research School of Asian, African and Amerindian studies (CNWS), Universiteit Leiden.

Nergård, M. E. \& Nicolaisen, T. (2016). Om å utforske den skjulte literacy i flerspråklige klasserom - mangfold som ressurs i undervisning. I I. M. Lindboe, G. T. Randen, T. Skrefsrud \& S. Østberg (Red.), Refleksjon og relevans: språklig og kulturelt mangfold i lcererutdanningene (s. 43-63). Vallset: Oplandske Bokforlag.

Penne, S. (2006). Profesjonsfaget norsk $i$ en endringstid: Norsk på ungdomstrinnet. Å konstruere mening, selvforståelse og identitet gjennom språk og tekster. Fagets rolle $i$ et identitsperspektiv, $i$ et likhet- og et ulikhetsperspektiv (Doktoravhandling, Universitetet i Oslo). Hentet fra https:/www.uv.uio.no/ils/forskning/publikasjoner/ rapporter-og-avhandlingen/Penne $\% 5 \mathrm{~B} 1 \% 5 \mathrm{D}$.pdf

Pitkänen-Huhta, A. \& Holm, L. (2012). Literacy practices in transition: perspectives from the nordic countries. Bristol: Multilingual matters.

Rosenblatt, L. M. (1994). The reader the text the poem: The transactional theory of the literary work; with a new preface and epilogue. Carbondale: Southern Illinois University Press. (Utgitt 1978).

Rosenblatt, L. M. (1995). Literature as exploration (5. utg.). New York: Modern Language Association of America. (Utgitt 1938).

Rødnes, K. A. (2011). Elevers meningsskaping av norskfaglige tekster $i$ videregående skole. (Doktoravhandling), Universitetet i Oslo, Oslo.

Salinas, V. (2016). Og. Oslo: Cappelen Damm.

Samatar, S. S. (1982). Oral poetry and Somali nationalism: the case of Sayid Mahammad 'Abdille Hasan. Cambridge: Cambridge University Press. https://doi.org/10.1017/CBO9780511735370

Samatar, S. S. (2010). Somalia: A Nation's Literary Death Tops Its Political Demise. I M. V. Hoehne \& V. Luling (Red.), Milk and peace, drought and war (s. 205-220). London: Hurst \& Company.

Skarstein, D. (2013). Meningsdannelse og diversitet: En didaktisk undersøkelse av elevers lesninger av norskfagets littercere tekster (Doktoravhandling, Universitetet i Bergen). Hentet fra http://bora.uib.no/bitstream/handle/ 1956/7694/dr-thesis-2013-Dag-Skarstein.pdf?sequence=1\&isAllowed=y

Starkey, P. (2006). Modern Arabic literature. Edinburgh: Edinburgh University Press.

Street, B. V. (1984). Literacy in theory and practice. Cambridge: Cambridge University Press.

Tahhan, S. (2004). Folktales from Syria (A. Rugh, Overs.). Austin: Center for Middle Eastern Studies, The University of Texas.

Tengberg, M. (2011). Samtalets möjligheter: om litteratursamtal och litteraturreception $i$ skolan. Stockholm: Brutus Östlings Bokförlag Symposion.

Vold, T. (2019). A lese verden: fra imperieblikk og postkolonialisme til verdenslitteratur og økokritikk. Oslo: Universitetsforlaget. 